\title{
Dropouts Against Early Marriage in Adolescents in Potil Pololoba Village, Banggai District, Banggai Laut Regency, Central Sulawesi Province
}

\author{
Tety Ripursari, Ida Sukmawati \\ Fuadi, Eri Puji Kumalasari \\ Institute of Health Science \\ STRADA Indonesia \\ Email: \\ tetty30578ripursari@gmail.com
}

Received : October $4^{\text {nd }} 2021$

Accepted : October $15^{\text {rd }} 2021$

Published : November $27^{\text {th }} 2021$

\begin{abstract}
One of the problems related to the reproductive system in adolescents that really needs special attention is the incidence of marriage at a young age, namely under the age of 19 years on the grounds that by marrying young, mothers will still be healthy and active at work when their children grow up and can Avoid getting pregnant out of wedlock. The purpose of this study was to determine the effect of dropping out of school on early marriage in Potil Pololoba Village, Banggai District, Banggai Laut Regency, Central Sulawesi Province.

The design of this research is correlational research with cross sectional approach. Respondents were taken by total sampling technique. The number of samples is 30 people. The independent variable is dropping out of school and the dependent variable is Early Marriage. The results were analyzed using the chi square statistical test.

The results showed that almost all respondents as many as 25 respondents $(83 \%)$ in the category of dropping out of school and most of the respondents as many as 21 respondents $(70 \%)$ in the category of occurring early marriage. The results of data analysis show that the significance level is $0.000<=0.05$ so that $\mathrm{H} 0$ is rejected and $\mathrm{H} 1$ is accepted, thus there is an effect of dropping out of school on early marriage in Potil Pololoba Village, Banggai District, Banggai Laut Regency, Central Sulawesi Province.
\end{abstract}

There is an effect of dropping out of school on early marriage.

Keywords: Dropout, early marriage, adolescents

Copyright @ 2021 IIK STRADA Indonesia All right reserved.

This is an open-acces article distributed under the terms of the Creative Commons AttributionShareAlike 4.0 International License.

\section{INTRODUCTION}

The number of cases of marriage at a young age, namely under the age of 19 years, is one of the problems related to the reproductive system in adolescents that requires special attention. Another reason is the thought that by marrying young, they will still be healthy and active at work when their children grow up who need money for education and other problems. In addition, there are other reasons that say that young marriage is better even if it is on the pretext of being entangled in promiscuity and avoiding pregnancy outside of marriage (Notoatmodjo, 2017).

According to the United Nations Fund for Population Activities (UNFPA) as the United 
Nations population organization, it is estimated that in 2020 there will be an increase in early marriage and annually it will reach 14.2 million, then in 2030 it is estimated that it will reach 15.1 million annually. Riskesdas (2021), In Indonesia, the number of married women aged 10-14 is 4.2 percent, while women aged 15-19 years are 41.8 percent married. In 2020 there will be an increase in the ratio of young marriages in urban areas, compared to rural areas. The number of these increases in urban areas in 2018 was 26 out of 1,000 marriages, the ratio rose in 2019 to 32 per 1,000 marriages. Meanwhile, in rural areas, it decreased from 72 per 1000 marriages to 67 per 1000 marriages in 2020. Despite an increase in the number of marriages in urban areas, the ratio of early marriage rates in rural areas is still higher than in urban areas. Reproductive health problems begin with early marriage, with the result that 2.6 percent of women aged 10-54 years are married at the age of less than 15 years, then 23.9 percent are married at the age of 15-19 years (Riskesdas, 2021).

Survey data obtained from Banggai District, Banggai Laut Regency, Central Sulawesi Province, found that the number of married ages less than 14 years was $0.5 \%$, while the married age between 15 years to 19 years was 33.5\%. The results of the survey in Potil Pololoba Village found that 30 out of school teenagers married at an early age. The results of a preliminary study conducted by researchers with interviews with 10 teenagers revealed that $5(50 \%)$ young women said they did not know about the impact of early marriage. Teenagers marry at a young age because they want to help and lighten the burden on their parents, the intention is to have children at a young age. 3 (30\%) adolescents said that parents support adolescents to marry at a young age, parents do not know the impact that occurs on marriage at a young age. While $2(20 \%)$ teenagers married at an early age because they were influenced by peers, family economic factors that caused teenagers to marry at an early age (Results of Preliminary Study with Interviews with Respondents in Potil Pololoba Village, Banggai District, Banggai Laut Regency, Central Sulawesi Province, 2021) .

Factors that influence dropping out include internal factors such as factors from within the child, the influence of peers, children who are sanctioned for missing school, the application of sanctions and external factors such as the state of the family's economic status, parental attention, parental relationships are less harmonious. (broken family), lack of interest in children to go to school, children are lazy to go to school, lack of school infrastructure. Besides that, the education of children can also lead to early marriage. In one's life, in dealing with problems and making decisions, including things that are more complex or psychosocial maturity is strongly influenced by a person's level of education. The low level of education and knowledge of children can lead to a tendency to marry at an early age. Young adolescents with low education are at risk for early marriage than young adolescents with higher education. Adolescents who have a high educational background have a lower risk of getting married early than those with a low educational background. Education level is one of the factors that influence a person in addressing problems and making decisions or psychosocial maturity (Notoatmodjo, 2017).

Therefore, it is expected that the role of parents also determines adolescents to undergo marriage at a young age. Parents also have a big role in delaying their child's marriage age. The role of parents is very important in making decisions to marry at a young age where the decision to marry at a young age is a decision related to the background of the relationship that is built between parents and children with their circle of friends. The function and role of the family is also realized that it can make a positive contribution in reducing the number of young marriages and the negative impact of young marriage itself, through child protection parenting, the form of protection intended in this case is parenting in educating and providing general knowledge and religion to children, life experiences, provision of provisions for physical, mental and socio-economic maturity as preparation for life in the future, especially in married life.

\section{OBJECTIVE}

The purpose of this study was to determine the effect of dropping out of school on early marriage in Potil Pololoba Village, Banggai District, Banggai Laut Regency, Central Sulawesi Province. 


\section{METHODS}

The research design used in the study is correlational research, namely the research method to determine the relationship between two or more variables (Notoatmodjo, 2017). The approach used in this study is cross sectional, namely research that aims to determine the relationship or influence of two or more variables with a data collection process that is only done once for each research variable. This type of research seeks to study the dynamics of the relationship or correlation between risk factors and their impact or effect.

The population in this study were all teenagers who dropped out of school in Potil Pololoba Village, Banggai District, Banggai Laut Regency, Central Sulawesi Province. A total of 30 people. The sample used in this study were all teenagers who dropped out of school in Potil Pololoba Village, Banggai District, Banggai Laut Regency, Central Sulawesi Province. The sampling technique in this study uses total sampling, which is a sampling technique where the number of samples is the same as the population. In this study, the independent variable is Drop Out, while the dependent variable is Early Marriage. This research was conducted in Potil Pololoba Village, Banggai District, Banggai Laut Regency, Central Sulawesi Province, which was carried out on July 25-August 2, 2021.

\section{RESULTS}

A. Socio-Demographic Characteristics of All Respondents Under Study

1. General Data

Table 1. Age of Respondents in Potil Pololoba Village, Banggai District, Banggai Laut Regency, Central Sulawesi Province

\begin{tabular}{cccc}
\hline No & Age & Frequency & Percentage (\%) \\
\hline 1 & $<15$ Years & 3 & 10 \\
\hline 2 & $16-17$ Years & 25 & 83 \\
\hline 3 & $18-19$ Years & 2 & 7 \\
\hline & Total & $\mathbf{3 0}$ & $\mathbf{1 0 0}$ \\
\hline
\end{tabular}

Based on table 1. Age of Respondents in Potil Pololoba Village, Banggai District, Banggai Laut Regency, Central Sulawesi Province, it is known that almost all respondents aged 16-17 years are as many as 25 respondents (83\%).

Table 2. Respondents' Residence in Potil Pololoba Village, Banggai District, Banggai Laut Regency, Central Sulawesi Province

\begin{tabular}{cccc}
\hline No & Residence & Frequency & Percentage (\%) \\
\hline 1 & Parent & 26 & 87 \\
\hline 2 & Grandpa/Grandmother/Uncle/Aunt & 1 & 3 \\
\hline 3 & Brother/Sister & 3 & 10 \\
\hline 4 & Distant Relatives & 0 & .0 \\
\hline & Total & $\mathbf{3 0}$ & $\mathbf{1 0 0}$ \\
\hline
\end{tabular}

Based on table 2. where respondents live in Potil Pololoba Village, Banggai District, Banggai Laut Regency, Central Sulawesi Province, it is known that almost all respondents live with their parents, as many as 26 respondents $(87 \%)$.

Table 3. Information on Early Marriage of Respondents in Potil Pololoba Village, Banggai District, Banggai Laut Regency, Central Sulawesi Province

\begin{tabular}{cccc}
\hline No & Information & Frequency & Percentage (\%) \\
\hline 1 & Ever & 26 & 87 \\
\hline 2 & Never & 4 & 13 \\
\hline & Total & $\mathbf{3 0}$ & $\mathbf{1 0 0}$ \\
\hline
\end{tabular}

Based on table 3. Information about Early Marriage of Respondents in Potil Pololoba Village, Banggai District, Banggai Laut Regency, Central Sulawesi Province, it is known that almost all respondents have received information about early marriage, as many as 26 respondents (87\%). 
Table 4. Sources of Information About Early Marriage of Respondents in Potil Pololoba Village,

Banggai District, Banggai Laut Regency, Central Sulawesi Province

\begin{tabular}{cccc}
\hline No & Sources Information & Frequency & Percentage (\%) \\
\hline 1 & Print Media & 0 & .0 \\
\hline 2 & Mass Media & 0 & .0 \\
\hline 3 & Elektronic Media & 13 & 43 \\
\hline 4 & Health Workers & 17 & 57 \\
\hline & Total & $\mathbf{3 0}$ & $\mathbf{1 0 0}$
\end{tabular}

Based on table 4. Sources of Information About Early Marriage in Respondents in Potil Pololoba Village, Banggai District, Banggai Laut Regency, Central Sulawesi Province, it is known that most of them received information about early marriage from health workers, namely 17 respondents (57\%).

2. Special Data

Table 5. Dropouts in Potil Pololoba Village, Banggai District, Banggai Laut Regency, Central Sulawesi Province

\begin{tabular}{cccc}
\hline No & Dropouts & Frequency & Percentage (\%) \\
\hline 1 & Happen & 25 & 83 \\
\hline 2 & Not Happen & 5 & 17 \\
\hline & Total & $\mathbf{3 0}$ & $\mathbf{1 0 0}$ \\
\hline
\end{tabular}

Based on table 5. Dropouts in Potil Pololoba Village, Banggai District, Banggai Laut Regency, Central Sulawesi Province, it is known that almost all respondents as many as 25 respondents (83\%) were in the category of occurring.

Table 6. Early Marriage in Potil Pololoba Village, Banggai District, Banggai Laut Regency, Central Sulawesi Province

\begin{tabular}{cccc}
\hline No & Early Marriage & Frequency & Percentage (\%) \\
\hline 1 & Happen & 21 & 70 \\
\hline 2 & Not Happen & 9 & 30 \\
\hline & Total & $\mathbf{3 0}$ & $\mathbf{1 0 0}$ \\
\hline
\end{tabular}

Based on table 6. Early Marriage in Potil Pololoba Village, Banggai District, Banggai Laut Regency, Central Sulawesi Province, it is known that most of the respondents as many as 21 respondents (70\%) were in the category of early marriage.

B. Cross-Tabulation Results Between General Data And Special Data

Table 7. Age with Dropouts in Potil Pololoba Village, Banggai District, Banggai Laut Regency, Central Sulawesi Province

\begin{tabular}{cccccc}
\hline & & \multicolumn{2}{c}{ Dropouts } & \\
\cline { 3 - 5 } & & & Not Happen & Happen & Total \\
\hline \multirow{2}{*}{ Age } & $<15$ Years & Frequency & 1 & 2 & 3 \\
\cline { 2 - 5 } & $\%$ & $4 \%$ & $6 \%$ & $10 \%$ \\
\cline { 2 - 5 } & \multirow{2}{*}{$16-17$ Years } & Frequency & 3 & 22 & 25 \\
\cline { 2 - 5 } & $\%$ & $10 \%$ & $73 \%$ & $83 \%$ \\
\cline { 2 - 5 } & \multirow{2}{*}{$18-19$ Years } & Frequency & 1 & 1 & 2 \\
\cline { 2 - 5 } & $\%$ & $3 \%$ & $4 \%$ & $3 \%$ \\
\hline \multirow{2}{*}{ Total } & Frequency & 5 & 25 & $100 \%$ \\
& & $\%$ & $17 \%$ & $83 \%$ & 30 \\
& & &
\end{tabular}

Based on table 7. Dropouts in Potil Pololoba Village, Banggai District, Banggai Laut Regency, Central Sulawesi Province, it is known that most of the respondents aged 16-17 years as many as 22 respondents $(73 \%)$ were in the category of occurring. 
Table 8. Age with Early Marriage in Potil Pololoba Village, Banggai District, Banggai Laut Regency, Central Sulawesi Province

\begin{tabular}{|c|c|c|c|c|c|}
\hline & & & \multicolumn{2}{|c|}{ Early Marriage } & \multirow[b]{2}{*}{ Total } \\
\hline & & & Not Happen & Happen & \\
\hline \multirow[t]{8}{*}{ Age } & \multirow[t]{2}{*}{$<15$ Years } & Frequency & 1 & 2 & 3 \\
\hline & & $\%$ & $2 \%$ & $8 \%$ & $10 \%$ \\
\hline & \multirow[t]{2}{*}{ 16-17 Years } & Frequency & 7 & 18 & 25 \\
\hline & & $\%$ & $25 \%$ & $58 \%$ & $83 \%$ \\
\hline & \multirow[t]{2}{*}{ 18-19 Years } & Frequency & 1 & 1 & 2 \\
\hline & & $\%$ & $3 \%$ & $4 \%$ & $7 \%$ \\
\hline & \multirow[t]{2}{*}{ Total } & Frequency & 9 & 21 & 30 \\
\hline & & $\%$ & $30 \%$ & $70 \%$ & $100 \%$ \\
\hline
\end{tabular}

Based on table 8. Early Marriage in Potil Pololoba Village, Banggai District, Banggai Laut Regency, Central Sulawesi Province, it is known that most of the respondents aged 16-17 years were 18 respondents $(58 \%)$ in the category of early marriage.

Table 9. Residence with Dropouts in Potil Pololoba Village, Banggai District, Banggai Laut Regency, Central Sulawesi Province

\begin{tabular}{|c|c|c|c|c|c|}
\hline & & & \multicolumn{2}{|c|}{ Dropouts } & \multirow{2}{*}{ Total } \\
\hline & & & Not Happen & Happen & \\
\hline \multirow[t]{8}{*}{ Residence } & \multirow[t]{2}{*}{ Parent } & Frequency & 4 & 22 & 26 \\
\hline & & $\%$ & $14 \%$ & $73 \%$ & $87 \%$ \\
\hline & \multirow{2}{*}{$\begin{array}{r}\text { Grandpa/Grandmother/Un } \\
\text { cle/Aunt }\end{array}$} & Frequency & 1 & 0 & 1 \\
\hline & & $\%$ & $3 \%$ & $.0 \%$ & $3 \%$ \\
\hline & \multirow[t]{2}{*}{ Brother/Sister } & Frequency & 0 & 3 & 3 \\
\hline & & $\%$ & $.0 \%$ & $10 \%$ & $10 \%$ \\
\hline & \multirow[t]{2}{*}{ Distance Relatives } & Frequency & 0 & 0 & 0 \\
\hline & & $\%$ & $.0 \%$ & $.0 \%$ & $.0 \%$ \\
\hline \multirow{2}{*}{\multicolumn{2}{|c|}{ Total }} & Frequency & 5 & 25 & 30 \\
\hline & & $\%$ & $17 \%$ & $83 \%$ & $100 \%$ \\
\hline
\end{tabular}

Based on table 9. Dropouts in Potil Pololoba Village, Banggai District, Banggai Laut Regency, Central Sulawesi Province, it is known that most of the respondents live with their parents, namely as many as 22 respondents $(73 \%)$ in the category of occurrence.

Table 10. Residence with Early Marriage in Potil Pololoba Village, Banggai District, Banggai Laut Regency, Central Sulawesi Province

\begin{tabular}{|c|c|c|c|c|c|}
\hline & & & \multicolumn{2}{|c|}{ Early Marriage } & \multirow{2}{*}{ Total } \\
\hline & & & Not Happen & Happen & \\
\hline \multirow[t]{8}{*}{ Residence } & Parent & Frequency & 6 & 20 & 26 \\
\hline & & $\%$ & $21 \%$ & $66 \%$ & $87 \%$ \\
\hline & $\begin{array}{c}\text { Grandpa/Grandmother/ } \\
\text { Uncle/Aunt }\end{array}$ & Frequency & 1 & 0 & 1 \\
\hline & & $\%$ & $3 \%$ & $.0 \%$ & $3 \%$ \\
\hline & Brother/Sister & Frequency & 2 & 1 & 3 \\
\hline & & $\%$ & $6 \%$ & $4 \%$ & $10 \%$ \\
\hline & Distance Relatives & Frequency & 0 & 0 & 0 \\
\hline & & $\%$ & $.0 \%$ & $.0 \%$ & $.0 \%$ \\
\hline \multirow{2}{*}{\multicolumn{2}{|c|}{ Total }} & Frequency & 9 & 21 & 30 \\
\hline & & $\%$ & $30 \%$ & $70 \%$ & $100 \%$ \\
\hline
\end{tabular}


Based on table 10. Early Marriage in Potil Pololoba Village, Banggai District, Banggai Laut Regency, Central Sulawesi Province, it is known that most of the respondents live with their parents, as many as 20 respondents $(66 \%)$ in the category of early marriage.

Table 11. Information on Early Marriage with Dropouts in Potil Pololoba Village, Banggai District, Banggai Laut Regency, Central Sulawesi Province

\begin{tabular}{cccccc}
\hline & & \multicolumn{2}{c}{ Dropouts } & \\
\cline { 3 - 5 } & & & Not Happen & Happen & Total \\
\hline \multirow{2}{*}{ Information } & \multirow{2}{*}{ Never } & Frekuensi & 4 & 22 & 26 \\
\cline { 2 - 5 } & & $\%$ & $14 \%$ & $73 \%$ & $87 \%$ \\
\cline { 2 - 5 } & \multirow{2}{*}{ Ever } & Frekuensi & 1 & 3 & 4 \\
\cline { 2 - 5 } & & $\%$ & $3 \%$ & $10 \%$ & $13 \%$ \\
\hline \multirow{2}{*}{ Total } & Frekuensi & 5 & 25 & 30 \\
\cline { 2 - 5 } & & $\%$ & $17 \%$ & $83 \%$ & $100 \%$ \\
\hline
\end{tabular}

Based on table 11. Dropouts in Potil Pololoba Village, Banggai District, Banggai Laut Regency, Central Sulawesi Province, it is known that most of the respondents never received information about early marriage, as many as 22 respondents $(73 \%)$ were in the category of occurrence.

Table 12. Information on Early Marriage with Early Marriage in Potil Pololoba Village, Banggai District, Banggai Laut Regency, Central Sulawesi Province

\begin{tabular}{cccccc}
\hline & & \multicolumn{2}{c}{ Early Marriage } & \\
\cline { 3 - 5 } & & & Not Happen & Happen & Total \\
\hline \multirow{3}{*}{ Information } & \multirow{2}{*}{ Never } & Frequency & 7 & 19 & 26 \\
\cline { 2 - 5 } & \multirow{2}{*}{ Ever } & $\%$ & $24 \%$ & $63 \%$ & $87 \%$ \\
\cline { 2 - 5 } & & Frequency & 2 & 2 & 4 \\
\cline { 2 - 5 } & $\%$ & $6 \%$ & $7 \%$ & $13 \%$ \\
\hline \multirow{2}{*}{ Total } & Frequency & 9 & 21 & 30 \\
\cline { 2 - 5 } & & $\%$ & $30 \%$ & $70 \%$ & $100 \%$ \\
\hline
\end{tabular}

Based on table 12. Early Marriage with Early Marriage in Potil Pololoba Village, Banggai District, Banggai Laut Regency, Central Sulawesi Province, it is known that most of the respondents had received information about early marriage, as many as 19 respondents (63\%) in the category of early marriage.

Table13. Sources of Information About Early Marriage With Dropouts in Potil Pololoba Village, Banggai District, Banggai Laut Regency, Central Sulawesi Province

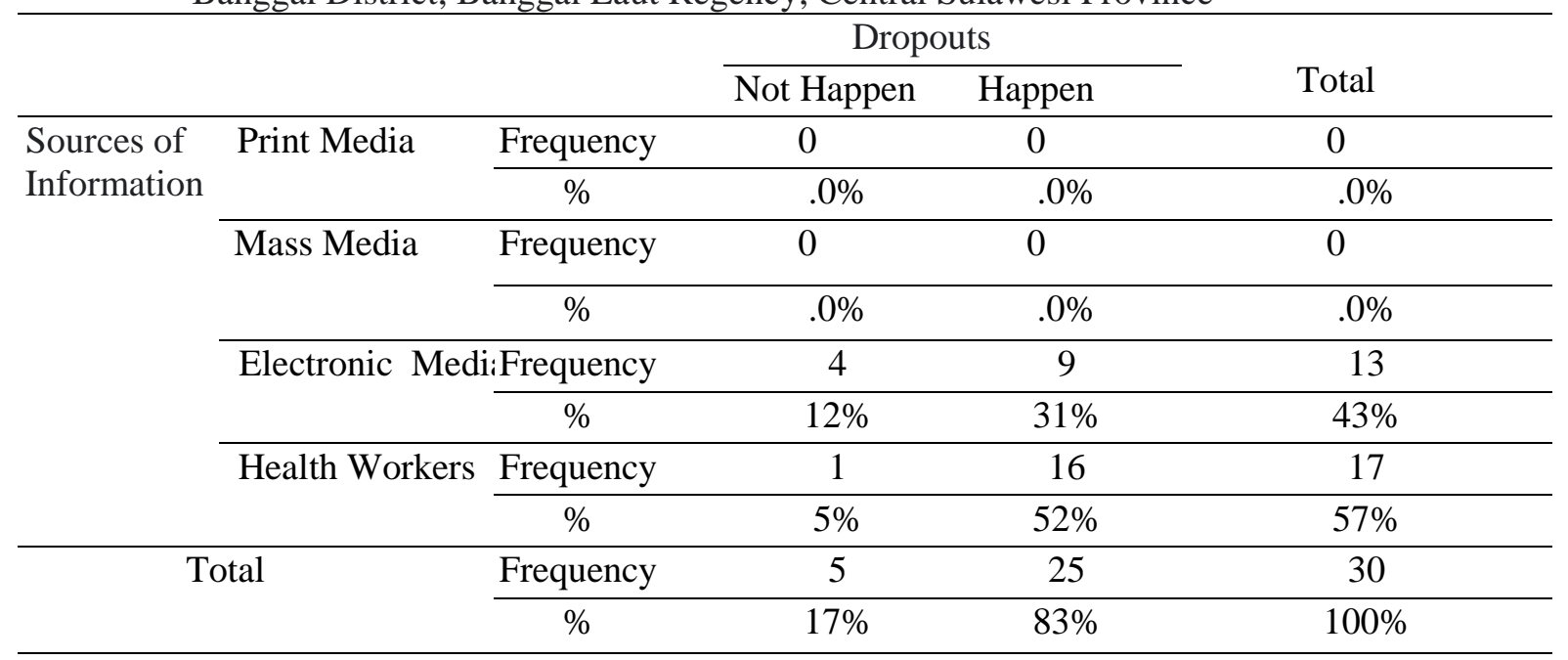

Based on table 13. Dropouts in Potil Pololoba Village, Banggai District, Banggai Laut Regency, Central Sulawesi Province, it is known that most of the respondents received information about early marriage from health workers, as many as 16 respondents $(52 \%)$ in the occurred category. 
Table 14. Sources of Information About Early Marriage with Early Marriage in Potil Pololoba Village, Banggai District, Banggai Laut Regency, Central Sulawesi Province

\begin{tabular}{|c|c|c|c|c|c|}
\hline & & & Early N & iage & \\
\hline & & & Not Happen & Happen & Total \\
\hline Sources of & Print Media & Frequency & 0 & 0 & 0 \\
\hline Information & & $\%$ & $.0 \%$ & $.0 \%$ & $.0 \%$ \\
\hline & Mass Media & Frequency & 0 & 0 & 0 \\
\hline & & $\%$ & $.0 \%$ & $.0 \%$ & $.0 \%$ \\
\hline & Electronic Media & Frequency & 8 & 5 & 13 \\
\hline & & $\%$ & $25 \%$ & $18 \%$ & $43 \%$ \\
\hline & Health Workers & Frequency & 1 & 16 & 17 \\
\hline & & $\%$ & $5 \%$ & $52 \%$ & $57 \%$ \\
\hline & Total & Frequency & 9 & 21 & 30 \\
\hline & & $\%$ & $30 \%$ & $70 \%$ & $100 \%$ \\
\hline
\end{tabular}

Based on table 14. Early Marriage in Potil Pololoba Village, Banggai District, Banggai Laut Regency, Central Sulawesi Province, it is known that most respondents received information about early marriage from health workers, namely 16 respondents $(52 \%)$ in the category of early marriage.

C. Cross Tabulation Results Between Independent And Dependent Variables

Table 15. Cross Tabulation Between Dropping Out Of School with Early Marriage in Potil Pololoba Village, Banggai District, Banggai Laut Regency, Central Sulawesi Province

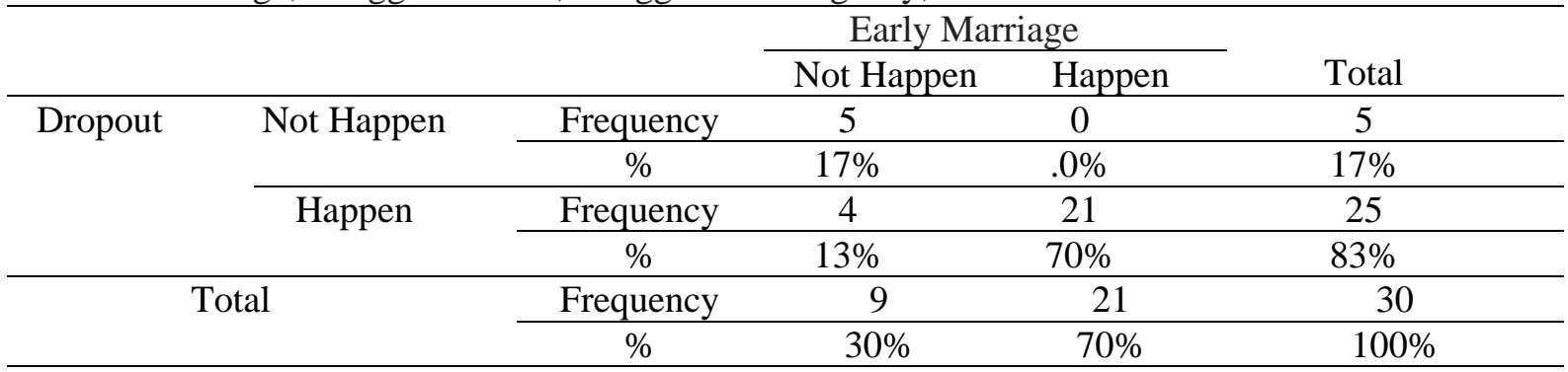

Based on table 15. the results of the cross tabulation between dropping out of school and early marriage in Potil Pololoba Village, Banggai District, Banggai Laut Regency, Central Sulawesi Province, it is known that most of the respondents, namely 21 respondents $(70 \%)$ in the category of early marriage.

D. Data Analysis

Table 16 Data Analysis Dropouts on Early Marriage in Potil Pololoba Village, Banggai District, Banggai Laut Regency, Central Sulawesi Province (Chi Square)

\begin{tabular}{ll}
\hline Variable & Signivicance Level \\
\hline Dropout & 0.000 \\
\hline Early Marriage &
\end{tabular}

The results of data analysis show that the significance level is $0.000<=0.005$ so that H0 is rejected and $\mathrm{H} 1$ is accepted thus There is an effect of Dropouts on Early Marriage in Potil Pololoba Village, Banggai District, Banggai Laut Regency, Central Sulawesi Province.

\section{DISCUSSION}

A. Dropouts for Children in Potil Pololoba Village, Banggai District, Banggai Laut Regency, Central Sulawesi Province

Based on the results of the study, it is known that dropping out of school in Potil Pololoba Village, Banggai District, Banggai Laut Regency, Central Sulawesi Province, it is known that almost all respondents as many as 25 respondents $(83 \%)$ in the category occur. This is in accordance with the results of the questionnaire that the respondents experienced dropping out of school so that it triggers 
a sense of inferiority in everyday life. Respondents were less open to self-development and were even more lazy than usual. One respondent said that dropping out of school caused his life to seem out of control and he had no purpose in life. In addition, respondents also feel that they have no aspirations to lose their direction in life. Besides that, one respondent also said that the impact of dropping out of school caused respondents to become less knowledgeable and even become lazy, frustrated and become stubborn and naughty which would result in uncontrolled free sex behavior and an impact on early marriage.

Pohan (2017), said that the impact of marriage at a young age was more evident in adolescent girls than adolescent boys. The real impact of early marriage is the occurrence of abortion or miscarriage because physiologically the reproductive organs (especially the uterus) are not yet perfect. The increasing number of divorce cases in young couples is due to the fact that in general young couples are not yet mature psychologically, so they are still unstable in dealing with problems that arise in marriage. In terms of socio-economic problems, early marriage is usually followed by economic unpreparedness.

In the opinion of the researcher that with teenagers dropping out of school and getting married early because teenagers don't want to be a burden on their parents, the solution to overcome it all is by getting married because by marrying a husband who has a job and has income so they can ease the burden on parents and can be separated from parents because of responsibility. Besides that, it is also the perception of teenagers that by doing early marriage in order to meet the expectations of parents because by marrying the responsibility is the responsibility of the husband, not the parents anymore so that the burden on the parents is reduced. Adolescents choose to drop out of school and marry at a young age because of family economic factors that demand the behavior of children to fall into marriage at a young age. The minimal family income is caused by the irregular work of parents as well as working as laborers, thus it will affect the perception of children that dropping out of school and getting married at a young age will be able to help their parents' income. Thus the economic level in the family is the cause of teenagers getting married at an early age because of the perception of teenagers that by getting married at an early age can help parents work every day and can also help income in the family. Marriage is something that happens when the couple is really feeling capable both in terms of age, preparation and mental spiritual development. But sometimes there are marriages that occur when their age is still too early which is dangerous for the mother and fetus in the womb and even the death of the mother and baby. So the need for socialization from various parties, both local government, health workers, school agencies, traditional leaders, religious leaders in providing information to the community, especially teenagers about the importance of school for teenagers and the impact of marrying at a young age. Thus, the information provided can add insight to adolescents in avoiding marriage at a young age and being able to continue their education to a higher level.

\section{B. Early Marriage in Potil Pololoba Village, Banggai District, Banggai Laut Regency, Central Sulawesi Province}

Based on the results of the study, it was found that early marriage in Potil Pololoba Village, Banggai District, Banggai Laut Regency, Central Sulawesi Province, it was known that most of the respondents were 21 respondents $(70 \%)$ in the category of early marriage. This shows that children marry young of their own volition and children who are no longer in school who do not have activities at home or are unemployed, which will be easily influenced to negative things, because they have a lot of time to interact with people. surroundings. And it is children who drop out of school who often marry at a young age for fear of bringing shame to the family later on. Self Desire Factor. The reason many children or teenagers decide to get married early is because they want to get married soon. The reason they got married was only based on the love between them without thinking about their needs after marriage. The reason is very simple, namely because it was love between the two to decide to get married early.

Prawirohardjo (2017), said that pregnancy at a young age (under 20 years) has several unfavorable impacts and also tends to be dangerous, both for the mother and the fetus. Here are some of the dangers of getting pregnant at a young age, including miscarriage, susceptibility to venereal disease, premature birth, risk of abnormalities in babies, postpartum depression, lack of knowledge of pregnant women, risk of maternal and child mortality. In the opinion of researchers, marriage at a young age will result in the safety of the mother and fetus at the time of delivery and even the death of 
the mother and fetus.

The occurrence of early marriage can also be caused by the influence and even coercion of parents. There are several reasons for parents to marry off their children early, because they are afraid that their children will fall into promiscuity and have negative consequences. Because he wants to perpetuate his relationship with his relationship by matching his child. Also matchmaking with his brother's children so that his property does not fall in the hands of others, but is still held by the family. The occurrence of pregnancy out of wedlock, because the children have a relationship that violates the norms, forcing them to have an early marriage, in order to clarify the status of the child being conceived. This marriage forces them to marry and are responsible for acting as husband and wife as well as being father and mother, so this will have an impact on premature aging, because they are not ready physically and mentally. In addition, with pregnancy outside of marriage and the fear of parents getting pregnant outside of marriage, it encourages their children to marry at a young age (Adhim, 2020).

According to the researcher's opinion, teenagers do early marriages that come from individual factors because they want to escape from the influence of their parents and can ease the burden on their parents, besides that they are tired of dating their partners, therefore they want to try new things. Besides that, teenagers also say that after marriage they can become adults. Another factor that comes from the individual is not going to school anymore. From an economic point of view, they want to promote a higher economic status. The wrong assumption about teenagers is that they think that by getting married at a young age, reproductive health will function optimally and be better maintained. Early marriage poses a greater risk to adolescent girls, especially in terms of their reproductive health. Adolescents who marry early, both physically and biologically are not mature enough to have children, so they are vulnerable to causing the death of children and mothers during childbirth. Sociocultural aspects of society have an influence on the implementation of early marriage. The low knowledge of adolescents about reproductive health, low parental education causes adolescents to choose to drop out of school which is at risk for early marriage. Thus, reproductive health education from an early age is the first step and a fairly effective way to balance the unbalanced flow of information for adolescents related to reproductive health and sexuality. In addition, to suppress the rate of marriage at an early age where the need for the role of fiber from various parties such as religious leaders, health workers, teachers, parents, traditional leaders and so on in order to prevent early marriage at a young age.

\section{Dropouts on Early Marriage in Potil Pololoba Village, Banggai District, Banggai Laut Regency,} Central Sulawesi Province

The results of data analysis show that the significance level is $0.000<=0.005$ so that $\mathrm{H} 0$ is rejected and H1 is accepted thus there is an effect of Dropouts on Early Marriage in Potil Pololoba Village, Banggai District, Banggai Laut Regency, Central Sulawesi Province. Based on the results of the cross tabulation between dropping out of school and early marriage in Potil Pololoba Village, Banggai District, Banggai Laut Regency, Central Sulawesi Province, it is known that most of the respondents, namely 21 respondents $(70 \%)$ in the category of early marriage. This is due to the low knowledge of adolescents and their parents, low education of people, family economic factors in the poor category, customs, perceptions of teenagers marrying at an early age, peer influence so that it has an impact on early marriage. In addition, it is undeniable that couples who have married early cannot fulfill or do not know their rights and obligations as husband and wife. This arises because there is no physical or mental maturity of both so that the egoism of each is very high. Early marriage usually causes various domestic problems such as quarrels, squabbles and prolonged conflicts, which can lead to divorce.

Parental education also has a role in decisions for their children, because in this family environment, children's education is first and foremost. The role of parents in the continuity of early marriage is basically inseparable from the level of parental knowledge which is also associated with the level of parental education. Adolescents who have low-educated parental backgrounds have a greater risk of getting married early than adolescents who have highly-educated parental backgrounds. One of the factors that can influence the decision of parents towards their children, one of which stands out is the factor of family education (Notoatmodjo, 2017).

In the opinion of researchers, the role of parents determines adolescents to undergo marriage 
at a young age. Parents also have a big role in delaying their child's marriage age. The role of parents is very important in making the decision to marry at a young age where the decision to marry at a young age is a decision related to the background of the relationship that is built between parents and children with their circle of friends. The function and role of the family is also realized that it can make a positive contribution in reducing the number of young marriages and the negative impact of young marriage itself, through child protection parenting, the form of protection intended in this case is parenting in educating and providing general knowledge and religion to children, life experiences, provision of provisions for physical, mental and socio-economic maturity as preparation for life in the future, especially in married life.

\section{CONCLUSION}

Based on the results of the study, it can be concluded as follows:

1. Almost all respondents as many as 25 respondents $(83 \%)$ in the category of dropping out of school in Potil Pololoba Village, Banggai District, Banggai Laut Regency, Central Sulawesi Province.

2. Most of the respondents were 21 respondents $(70 \%)$ in the category of early marriage in Potil Pololoba Village, Banggai District, Banggai Laut Regency, Central Sulawesi Province.

3. There is an effect of dropping out of school on early marriage in Potil Pololoba Village, Banggai District, Banggai Laut Regency, Central Sulawesi Province, where the results of $p$ value $0.000<=0.05$

\section{REFERENCES}

A.Aziz, Alimul Hidayat. 2017. Metode Penelitian Keperawatan Dan Teknik Analisis Data. Jakarta : Penerbit. Salemba Medika.

Adedevi, 2020. Konsep Peran Menurut Beberapa Ahli. http://carapedia.com/ pengertian definisi peran info 2184.html.pdf diakses tanggal 14 November 2020 pukul 17.00 WIB.

Ali, M dan Asrori, M. 2017. Psikologi Remaja. Jakarta : Bumi Aksara.

Alfiyah, 2018. Sebab-sebab Pernikahan Dini. Jakarta, EGC.

Al-Ghifari, Abu, 2017. Perkawinan Dini Dilema Generasi Ekstravagansa. Bandung: Mujahid.

Almatsier, 2019. Prinsip Dasar Ilmu Gizi. Jakarta: PT Gramedia Pustaka.

Al-Mighwar, Muhamad. 2016. Psikologi Remaja, Petunjuk Bagi Guru dan Orangtua. Bandung : Pustaka Setia.

Ahmad, Zulkifli. 2017. Dampak Sosial Pernikahan Usia Dini (Studi Kasus di Desa Gunung Sindur-Bogor. Skripsi (Tidak Diterbitkan). Jakarta: Program Studi Kesejahteraan Sosial, Fakultas Dakwah dan Komunikasi, Universitas Islam Hidayatullah.

Alwi, H. 2017. Kamus Besar Bahasa Indonesia. Jakarta: Balai Pustaka.

Darwis, S. D. 2017. Metode Penelitian. Jakarta : EGC.

DepKes RI. 2020. Profil Kesehatan Indonesia 2020 : Menuju Indonesia Sehat 2020. Jakarta : Departemen Kesehatan RI.

Dewi Ni Ayu Krisna, Anjuan Zukhri, I Ketut. 2018. “Analisis Faktor-Faktor Penyebab Anak Putus Sekolah Usia Pendidikan Dasar Di Kecamatan Gerokgrak Tahun 2012/2013”. Jurnal penelitian Universitas Pendidikan Ekonomi Ganesa Singaraja, Indonesia. Vol:4 no:1 tahun 2018. http://ejournal.undiksha.ac.id/index.php/JJPE/article/view/1898/1650.

Fatimah, Siti. 2019. Faktor-Faktor Penyebab Anak Putus Sekolah pada Jenjang Pendidikan Menengah (SMK/SMA) di Kecamatan Mijen Kota Semarang Kurun Waktu 2018-2019. Skripsi. FIS. UNNES.

Fitriana, 2015. "Identifikasi Faktor Penyebab Siswa Putus Sekolah di Sekolah Dasar Kota Yogyakarta". Skripsi. FIP. UNY.

Gunawan, Ari H. 2020. Sosiologi pendidikan: Suatu Analisis Sosiologi Tentang Pelbagai Problem Pendidikan. Jakarta: Rineka cipta Hartini, Sri dkk. 2018. Psikologi Pendidikan. Surakarta: BPFKIPUMS.

Jannah.F. 2016. Pernikahan Dini Dan Implikasinya Terhadap Kehidupan Keluarga Pada Masyarakat Madura (Perspektif Hukum dan Gender). Egalita.Vol.7 No.1. (Diunduh 16 September 2014).

Lily, A. 2017. "Perkawinan Dini Adalah Masalah Kita Bersama, Administrator, Tanggal 02 May, 
2017, Jam 07:40 wib.

Luthfiyah, D. 2018. Pernikahan Dini pada Kalangan Remaja (15-19 tahun). http://nyna0626.blogspot.com. (Diakses 4 Desember 2018).

Mohammad. M.D. 2015. Jeratan Nikah Dini, Wabah Pergaulan, Yogyakarta: Media Abadi.

Noorkasiani, Heryani \& Ismail, R 2017, Dampak dan faktor-faktor penyebab pernikahan dini pada remaja, ECG: Jakarta.

Notoatmodjo, Soekidjo. 2017. Metodologi Penelitian Kesehatan. Jakarta : Rineka Cipta.

Notoatmodjo, Soekidjo. 2017. Konsep Pengetahuan, Pendidikan dan Perilaku Kesehatan. Jakarta, EGC.

Nursalam, 2017. Konsep dan Penerapan Metodologi Penelitian Ilmu Keperawatan. Jakarta : Salemba Medika.

Puspitasari, Fitra, 2016. Perkawinan Usia Muda: Faktor-faktor Pendorong Dan Dampaknya Terhadap Pola Asuh Keluarga. Tasikmalaya: Tesis.

Rafidah, dkk. 2018. Faktor-faktor yang Berhubungan dengan Pernikahan Usia Dini di Kabupaten Purworejo Jateng. Berita Kedokteran Masyarakat, Vol.25, No.2. Hal: 51-58.

Santrock, J.W. 2017. Adolescence, Perkembangan Remaja. Jakarta: Erlangga.

Saputo, Adi Purnomo. 2019. "Faktor-Faktor Penyebab Anak Usia Sekolah Tidak Menyelesaikan Pendidikan Dasar (Studi Kasus di Desa Pesantren Kecamatan Blado Kabupaten Batang)". Skripsi. FIS. UNNES.

Soetjiningsih, 2018. Buku Ajar: Tumbuh Kembang Remaja dan Permasalahannya. Jakarta : Sagung Seto.

Sudirman, 2019. Interaksi Dan Motivasi Belajar Mengajar. Jakarta: PT. Raja Grafindo Persada.

Sugiyono, 2017. Metode Penelitian Kuantitatif Kualitatif Dan R\&D (Edisi Revisi). Bandung : CV. Alfabeta.

Willis, 2016. Problema Remaja dan Pemecahannya. Bandung: PT. Angkasa. 